\title{
Study of Sickle Cell Anemia with Clinical and Hematological Correlation (Provincial Hospital EL Idrissi, Morocco)
}

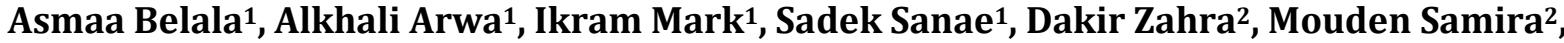 Driss Belghyti' ${ }^{1}$ Khadija El Kharrim ${ }^{1}$}

\author{
${ }^{1}$ Laboratory of Biotechnologies, Environment and Quality, University Ibn Tofail, Kénitra, Morocco \\ ${ }^{2}$ Laboratory Serological Laboratory Virology Laboratory, Provincial Hospital el Idrissi Kenitra, Kenitra, Morocco \\ Email: belalaasmaa@hotmail.fr
}

How to cite this paper: Belala, A, Arwa, A., Mark, I., Sanae, S., Zahra, D., Samira, M., Belghyti, D. and El Kharrim, K. (2017) Study of Sickle Cell Anemia with Clinical and Hematological Correlation (Provincial Hospital EL Idrissi, Morocco). Open Journal of Epidemiology, 7, 201-210.

https://doi.org/10.4236/ojepi.2017.72017

Received: March 19, 2017

Accepted: May 28, 2017

Published: May 31, 2017

Copyright $\odot 2017$ by authors and Scientific Research Publishing Inc. This work is licensed under the Creative Commons Attribution International License (CC BY 4.0).

http://creativecommons.org/licenses/by/4.0/

c) (i) Open Access

\begin{abstract}
Sickle cell anemia is an autosomal recessive genetic disease by mutation of the $\beta$ globin gene. This mutation induces the synthesis of abnormal hemoglobin $(\mathrm{Hb}) \mathrm{HbS}$, Mainly responsible for all clinical manifestations vaso-occlusives and chronic hemolysis with variable anemia. The objective of this study is the determination profile of haematological parameters of sickle cell children of the province of Kenitra (Morocco). In order to know the usual values and the particularities which are its own, we have observed that $50 \%$ of sickle cell children in our case study have severe anemia and $84 \%$ in patients aged 5 to 11 years. In addition, there is no significant difference among gender. The cases of hemoglobinosis $\mathrm{S}$ are divided into: Homozygous hemoglobinosis $\mathrm{S}$ (43\%), Heterozygous sickle cell disease (17\%), Hemoglobinosis S associated with alpha-thalassemia (1\%), Hemoglobinosis $\mathrm{S}$ composite heterozygosity S/beta-thalassemia (5\%), S/PHHF composite heterozygosity (6\%), eventually composite heterozygosity S/beta+ thalassemia (28\%). Homozygous sickle cell children have a long hospital stay, the highest number of hospitalizations and very severe sickle cell syndromes compared to the other phenotypic status of our population.
\end{abstract}

\section{Keywords}

Sickle Cell Anemia, Thalassemia-Haematological Parameters, Kenitra-Morrocco

\section{Introduction}

Sickle cell disease is the most common genetic disease in the world. 100 to 150 million people are healthy transmitters and 300,000 to 400,000 children per year 
worldwide are born with sickle cell disease [1]. Major sickle cell syndromes encompass three major genetic forms: homozygoties $S / S$, Composite heterozygosities $S / C$ and $S / \beta$ or $S / \beta+$ thalassemia. The most severe forms are S/S homozygosities as well as $S / \beta$ thalassemia. These syndromes mainly affect populations in sub-Saharan Africa, the Caribbean and North Africa. Confirmation of the diagnosis of sickle cell disease is based on the study of hemoglobin. This should be done at a distance from a transfusion. It confirms the presence of $\mathrm{HbS}(90 \%$ in homozygotes). The residual $\mathrm{HbF}$ level has an impact on the frequency of crises.

A large variability in haematological data is observed in these sickle cell patients according to the genotype, age and the gender of the patients, with differences depending on whether the examination is performed during a stable phase or during a crisis or complication.

It is characterized by three main categories of clinical manifestations [2], Chronic hemolytic anemia with periods of acute aggravation, extreme susceptibility to bacterial infections and vaso-occlusive seizures, which can touch different organs and which are statistically associated with cognitive degradation [3] [4] but also to other genetic factors not completely elucidated.

\section{Material and Methods}

\subsection{Population}

The province of Kenitra is a subdivision of the Moroccan region of Rabat-saléKenitra. Geographically, it is located on the Atlantic coast to the northwest of the Kingdom. It covers an area of $3500 \mathrm{~km}^{2}\left(4745 \mathrm{~km}^{2}\right.$ before the creation of the province of Sidi Slimane). That is $43.8 \%$ of the regional area.

\subsection{Method}

\subsubsection{Conduct of the Investigation}

The questionnaire made it possible to register age, gender, number of hospitalizations, duration of hospitalization and number of transfusions.

\subsubsection{Blood Count}

The hemograms were determined on an automaton of the type (coulter): This device for automatic haematological analysis, which provides information on white blood cells, platelets, red blood cells, hematocrit (Hte), hemoglobin $(\mathrm{Hb})$

\subsubsection{Computer Processing and Data Analysis}

We used the descriptive statistics tests which allowed us to calculate the average norm and the standard deviation, The XLSTAT was used to calculate the chisquare test.

\section{Result and Discussion}

\section{Distribution of Patients According to Hemoglobin (Hb)}

\section{At the Level of the Total Population}

For the biological diagnosis of anemia, we have retained WHO figures which define anemia from the following hemoglobin levels: 
Indeed, the World Health Organization assorts anemia in children as follows:

Light $(10$ to $11 \mathrm{~g} / \mathrm{dl})$, moderate $(7.5$ to $9.9 \mathrm{~g} / \mathrm{dl})$, severe $(<7.5 \mathrm{~g} / \mathrm{dl})$, life threatening if the hemoglobin level is less than $6.5 \mathrm{~g} / \mathrm{dl}$ (Figure 1).

The intensity of anemia is shown in Figure 1. Anemia in this population of children is $50 \%$ severe, $24 \%$ moderate and $26 \%$ suffers from mild anemia.

\section{At the Level of Gender Dependency}

Analysis of the distribution of hemoglobin levels in patients showed an average norm hemoglobin of $6.70 \mathrm{~g} / \mathrm{dl}$ with a standard deviation of $1.74 \mathrm{~g} / \mathrm{dl}$ It is 6.75 $\mathrm{g} / \mathrm{dl}$ in girls and $7.42 \mathrm{~g} / \mathrm{dl}$ in boys with no significant difference.

In girls, severe anemia (72\%) is higher than moderate anemia (28\%) compared to boys which frequencies are respectively $69 \%$ and $31 \%$ (Figure 2, Figure 3).

\section{According to Age}

Severe anemia is very distinct, involving $61 \%$ of sickle-cell anemia aged 6 to 59
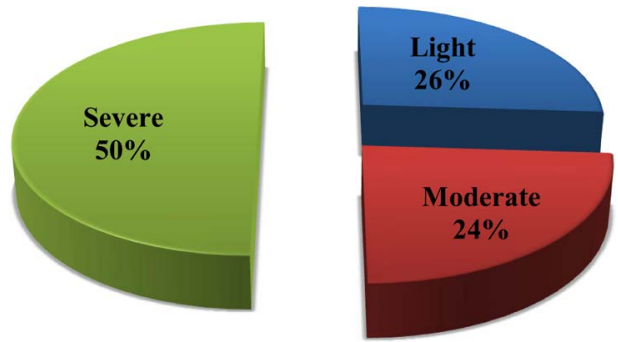

Figure 1. Intensity of anemia in sickle cell children.

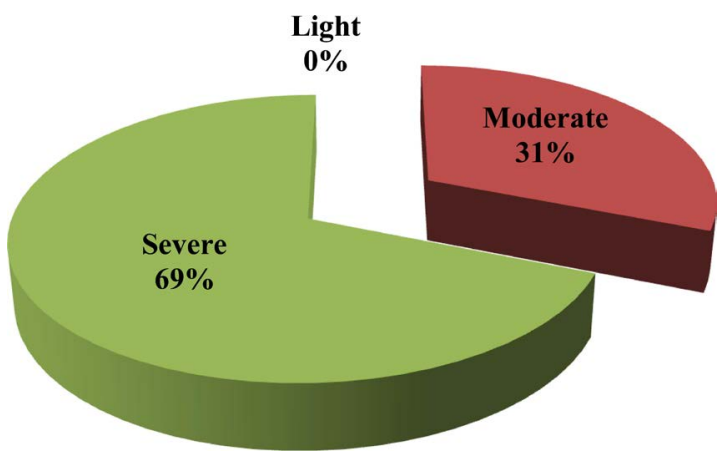

Figure 2. Intensity of anemia in sickle cell boys.

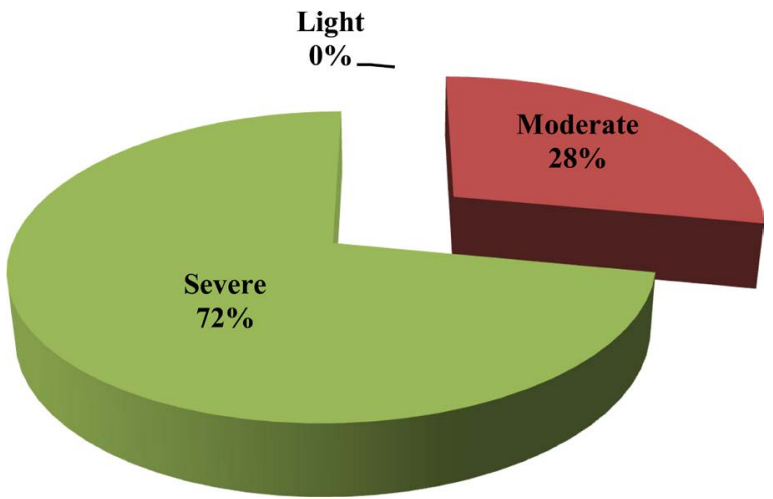

Figure 3. Intensity of anemia in girls with sickle cell anemia. 
months. This prevalence is $84 \%$ in patients aged 5 to 11 years and $65 \%$ in sicklecell patients aged 12 to 14 years. Moderate anemia wavers between $16 \%$ and $31 \%$, involves $31 \%$ of sickle-cell anemia aged between 6 and 59 months, $16 \%$ of patients aged between 5 and 11 years, 15\% of sickle cell children aged between 12 and 14 years (Table 1 ).

\section{Distribution of the Population by Phenotype}

Sickle cell disease or Herrick's disease is a hemoglobinopathy characterized by hereditary chronic haemolytic anemia associated with the presence of abnormal hemoglobin (HbS) in the blood (Figure 4).

Our results prove the existence of different types of phenotypes, among 86 patients who were identified in this heterozygous study, 37 homozygotes, 1 with associated $\alpha$-thalassemia sickle cell disease, 24 with sickle cell disease associated with $\beta+$-thalassemia, 4 with associated $\beta^{\circ}$ thalassemia disease and 5 with $\mathrm{S} / \mathrm{PHHF}$ composite heterozygosis.

\subsection{Relationship between Phenotype and Age of Diagnosis}

There is a wide difference among the phenotypes as regards the diagnosis average age of the disease ( $\mathrm{p}$ value $=0.98$, alpha $=0.01$ ):

Homozygous sickle cell and S/PHHF composite heterozygous patients have an average norm age of diagnosis of 2 years. However, the study carried out on patient sickle-cell heterozygote and S/beta + thalassemia, S/alpha-thalassemia and S/beta-thalassemia patients has an average norm age of diagnosis of 1 year (Figure 5).

Table 1. Distribution of anemia intensity in sickle cell patients by age.

\begin{tabular}{ccccccc}
\hline & \multicolumn{2}{c}{$6-59$ months } & \multicolumn{2}{c}{5 to 11 years old } & \multicolumn{2}{c}{12 to 14 years old } \\
\hline Severe & $61 \%$ & $0-7 \mathrm{~g} / \mathrm{dl}$ & $84 \%$ & $0-8$ & $85 \%$ & $0-8$ \\
Moderate & $31 \%$ & $7-9.9 \mathrm{~g}$ & $16 \%$ & $8-10.9$ & $15 \%$ & $8-9$ \\
Light & $8 \%$ & $10-10.9$ & $0 \%$ & $11-11.4$ & $0 \%$ & $11-11.9$ \\
\hline
\end{tabular}

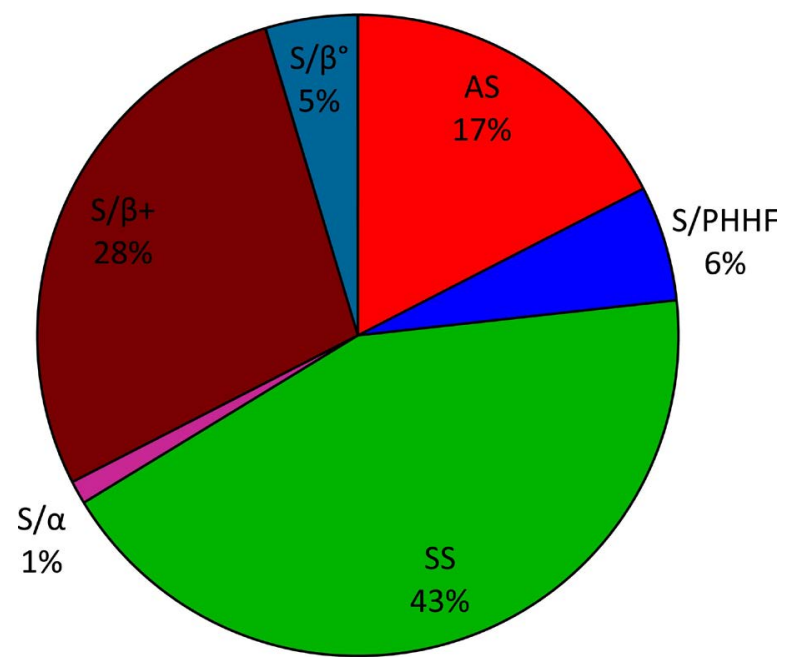

Figure 4. Distribution of sickle cell phenotypes in patients. 


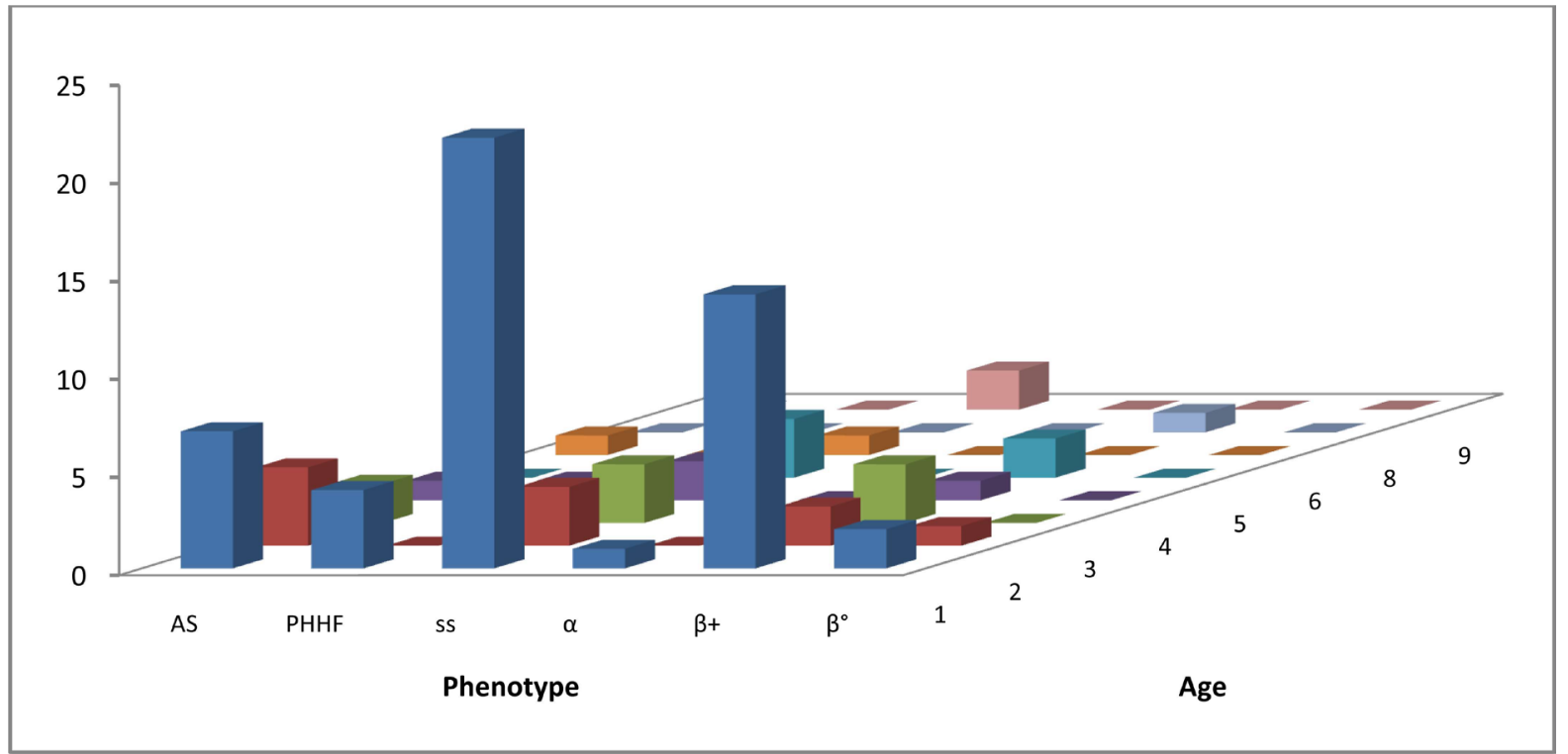

Figure 5. Relationship between phenotype and age of diagnosis.

Hence, it can be concluded that the age of the first symptom and the diagnosis were significantly earlier for HbSS children than for the other phenotypes.

Our study goes hand in hand with Diagne [5]. It can be thus concluded that the age of the first symptom and the diagnosis were significantly earlier for HbSS children than for other phenotypes.

\subsection{Relationship between Phenotype and Number of Hospitalizations}

All children with a heterozygous S-associated genetic status associated with alpha-thalassemia reported only 1 hospitalization per year, While $11 \%$ to $22 \%$ of homozygous patients (Fisher $=1.61$ ) and S/PHHF composite heterozygosis reported 4 to 6 hospitalizations per year $($ Fisher $=0.052)$.

In contrast, heterozygous $S$ patients associated with alpha-thalassemia and composite heterozygous S/beta-thalassemia patients reported only 2 to 3 hospitalizations per year $($ Fisher $=1.61)($ Figure 6$)$.

\subsection{Relationship between Phenotype and Duration of Hospitalization}

The 86 patients selected accounted for 307 days of hospitalization Homozygous children consumed $49 \%$ (Fisher $=-\mathbf{0 . 2 2 1}$ ) of these hospital days, heterozygous $18 \%$ (Fisher $=0.187$ ), heterozygous $\mathrm{S}$ associated with alpha-thalassemia $3 \%$ (Fisher $=-0.22)$, S/beta0-thalassemia composite heterozygosis 3\% (Fisher $=0$ ), S/PHHF composite heterozygosis (5\%), composite heterozygous S/beta + thalassemia 22\% (Fisher, -0.47) (Figure 7).

\subsection{The Relationship between Phenotype and Number of Transfusion}

The phenotype-transfusionrelationship was highly significant $(\mathrm{p}<0.05)$. The 


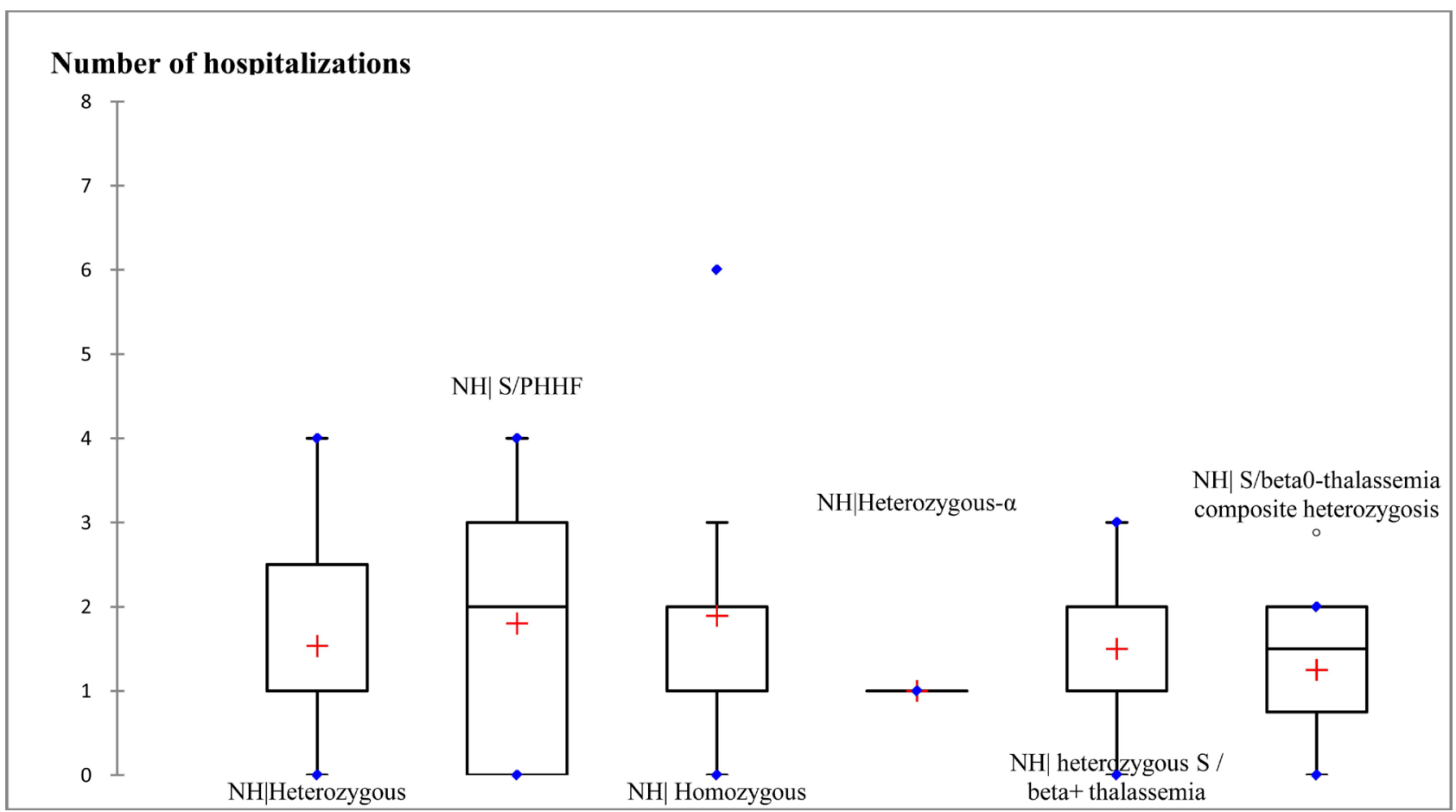

Figure 6. Relation between phenotype and number of hospitalizations ( $\mathrm{p}$-value $=0.05$ ).

\section{Duration of hospitalization}

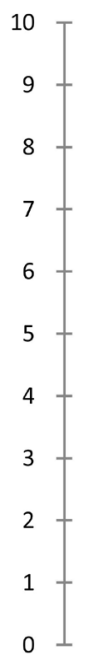

D| S/PHHF

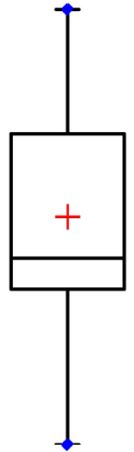

D/Heterozygous
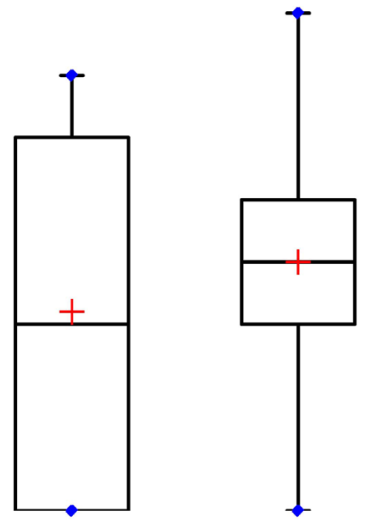

D/Homozygous
D $\mid$ Heterozygous S- $\alpha$
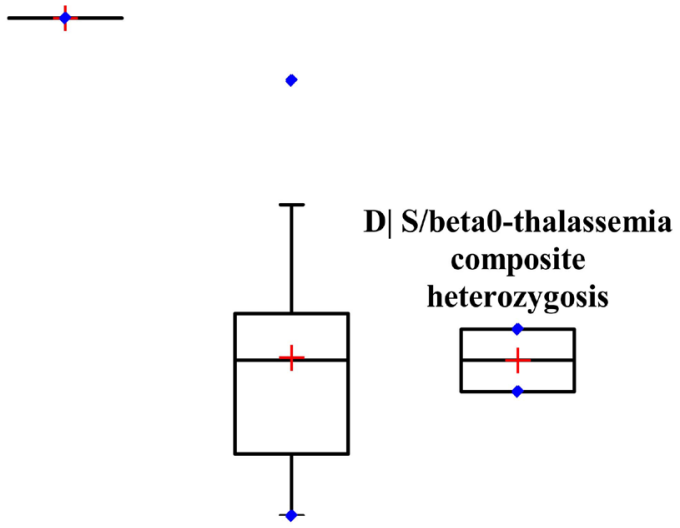

$\mathbf{D} \mid$ heterozygous $\mathbf{S}$ / beta + thalassemia

Figure 7. Relation between phenotype and duration of hospitalization $(\mathrm{p}=0.05)$.

maximum transfusion frequency was recorded in children with homozygous sickle cell disease $47 \%($ Fisher $=1.4)$ (Figure 8$)$.

\section{Discussion}

The commonly prescribed blood count or blood count (NFS) is not always easy to interpret at the pharmacy. It evaluates the quantity and quality of the red line 


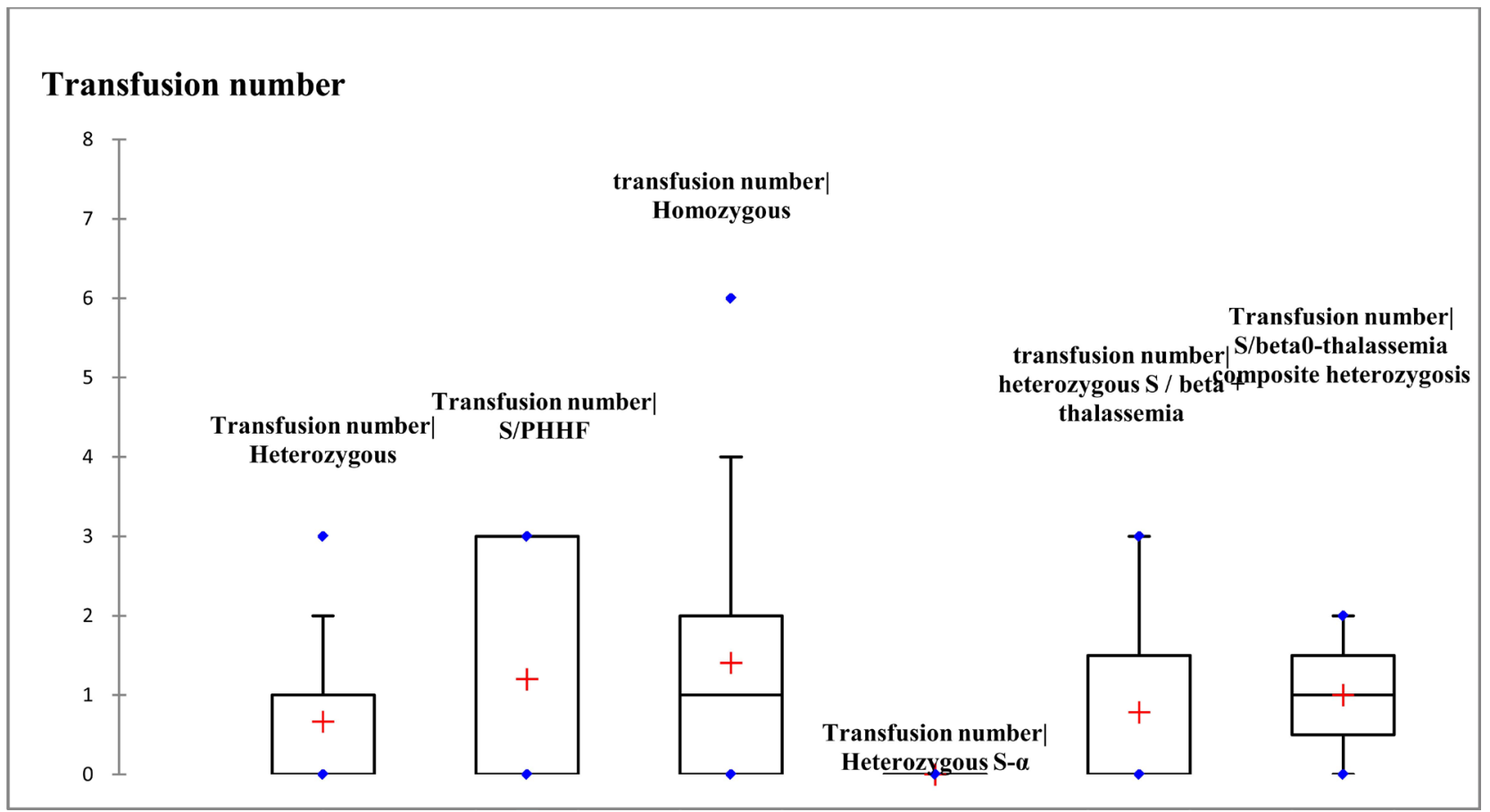

Figure 8. The Relationship between phenotype and the transfusion number $(\mathrm{p}<0.05)$.

(red blood cells), the white line (white blood cells) and the platelets. It is often required before a suspicion of anemia, an alteration of the general state In case of hemorrhage, thrombosis, Persistent infection or cancer. It is also prescribed for the monitoring of drug therapy [6]. Hemogram of sickle cell subjects in our study shows that severe anemia is very marked in $61 \%$ of sickle cell patients aged between 6 and 59 months. This result goes hand in hand with the studies of Makani [7]. Which revealed $71 \%$ of the sickle cell group investigated elderly present severe anemia, and a higher occurrence of death in the first three years of life [8] [9] [10]. Early detection at the birth of sickle-cell anemia and the institution of preventive care has improved the survival of patients [10] [11] [12] [13]. Besides, therapeutic education of parents at birth can be enrolled in care programs to ensure prompt and effective treatment of acute events and prophylaxis against complications, resulting in an impact on survival and quality of life.

In Africa, sickle-cell anemia occurs as a maximum frequency band of $30 \%$ in sub-Saharan Africa from west to east. This frequency decreases towards the north and south according to the migration currents. In Maghreb North Africa, this rate is $1 \%$ to $2 \%$.

Hemoglobinosis S ishomozygous (43\%), heterozygous sickle cell disease (17\%), hemoglobinosis $S$ is associated with alpha-thalassemia (1\%), hemoglobinosis $S$ composite heterozygosity S/beta0-thalassemia $5 \%$ ), Composite heterozygosity S/PHHF (6\%), composite heterozygosity S/beta + thalassemia (28\%). We note a discrepancy between our results and those: from the retrospective study carried out between January 1983 and December 2005, at the Department of Hematology and Pediatric Oncology of Casablanca (Morocco), 73 patients with major sickle cell syndrome were collected with 39 males and 34 females (sex ratio: 1, 
14). In 53 cases $(72 \%)$, heterozygous $\mathrm{S} / \mathrm{b}$-thalassemia were detected in 15 cases (21\%), 5 cases of $\mathrm{HbS} / \mathrm{C}(7 \%) .55 \%$ of patients have a first-degree relative with a major sickle cell syndrome. of the study carried out in 2000 in France during a neonatal screening of major sickle cell syndromes, of all 170 sickle cell children born in the metropolitan territory, 70\% are homozygous sickle-cell anemia and $20 \%$ are SC composite heterozygotes. The remaining $10 \%$ are thalasso-sickle cell syndromes.

Sickle cell anemia is a hereditary blood disorder that can lead to life-long pain [14]-[19], Homozygous patients have more severe complications associated with increased morbidity and mortality, especially in older adolescents Platt, Powars and Raphael [14] [20] [21].

It should be noted that alpha-thalassemia results in a decrease in $\mathrm{HbS}$, according to Sangare et al. who report that the presence of alpha-thalassemia significantly reduces the prevalence of sickle cell complications. Therefore, Embury et al [22]. report the beneficial effect of alpha thalassemia and sickle cell disease association on the symptomatology of sickle cell disease. Sickle cell syndromes cause real public health problems in many countries including Morocco, where their frequency and distribution are poorly known. A screening followed by a diagnosis made at birth, targeted at populations at risk, allows to identify the various genetic forms of major sickle cell syndromes and to institute an early management that reduces the incidence of serious complication allows to identify the various genetic forms of major sickle cell syndromes and to institute an early management reducing the incidence of serious complications.

\section{Conclusions}

Sickle-cell anemia is a real public health problem in Morocco. The prevalence of sickle cell trait is very high as well as the frequency of major forms. The heterozygous and sickle cell form associated with $\beta$-thalassemia is less severe than that homozygous especially in younger children.

Hemoglobinopathies are indeed a reality in our country. They deserve future investigations for a better control of its complications and its treatment.

As a result, they should be of greater interest especially in certain areas where the concentration of the disease is high.

\section{Acknowledgements}

Our thanks go to the Pediatric Department of the Provincial Hospital of Kenitra, Morocco.

\section{Conflicts of Interest}

The authors do not declare any conflicts of interest.

\section{References}

[1] Choudja Cécile Jérôme (2012) Les enfants avec une drépanocytose-Un mémento pour le pédiatre. Paediatrica, 23, 16-19. 
[2] Nacoulma, E., Sakande, J., Kafando, E., Kpowbié, E.D. and Guissou, I.P. (2006) Profil hématologique et biochimique des drépanocytaires SS et SC en phase stationnaire au Centre Hospitalier National Yalgado Ouedraogo de Ouagadougou. Le Mali Medical, 21, 8-11.

[3] Bernaudin, F., Verlhac, S. and Freard, F. (2000) Multicenter Prospective Study of Children with Sickle Cell Disease: Radiographic and Psychometric Correlation. Journal of Child Neurology, 15, 333-343. https://doi.org/10.1177/088307380001500510

[4] Najean, Y. (1991) Anémie: Orientation diagnostique. La Revue du Praticien, 41, 20. World Health Organization (1968) Nutritional Anaemias. WHO Technical Report Series No. 405, WHO Scientific Group, Geneva. http://whqlibdoc.who.int/trs/WHO_TRS_405.pdf

[5] Diagne, I., Ndiaye, O., Moreira, C., Stignate-Sy, H., Camara, B. and Diouf, S. (2007) Les syndromes drépanocytaires majeurs en Pédiatrie à Dakar (Sénégal). Arch Ped, 7, 16-24.

[6] Makani, et al. (2013) Berthélémy L’hémogramme ou numération-formule sanguine. Actualités Pharmaceutiques, 53, 53-55.

[7] Makani, J., Ofori-Acquah, S.F., Nnodu, O., Wonkam, A. and Ohene-Frempong, K. (2013) Sickle Cell Disease: New Opportunities and Challenges in Africa. The Scientific World Journal, 2013, Article ID: 193252.

[8] Gill, F.M., Sleeper, L.A. and Weiner, S. (1995) Clinical Events in the First Decade in a Cohort of Infants with Sickle Cell Disease. Blood, 86, 776-783.

[9] Leikin, S.L, Gallagher, D, Kinney, T.R, Sloane, D, Klug, P. and Rida, W. (1989) Mortality in Children and Adolescents with Sickle Cell Disease. Pediatrics, 84, 500-508.

[10] Lee, A., Thomas, P., Cupidore, L., Serjeant, B. and Serjeant, G. (1995) Improved Survival in Homozygous Sickle Cell Disease: Lessons from a Cohort Study. British Medical Journal, 311, 1600-1602. https://doi.org/10.1136/bmj.311.7020.1600

[11] Quinn, C.T., Rogers, Z.R., and Buchanan, G.R. (2004) Survival of Children with Sickle Cell Disease. Blood, 103, 4023-4027. https://doi.org/10.1182/blood-2003-11-3758

[12] Vichinsky, E., Hurst, D., Earles, A., Kleman, K. and Lubin, B. (1988) Newborn Screening for Sickle Cell Disease: Effect on Mortality. Pediatrics, 81, 749-755.

[13] Frempong, T. and Pearson, H.A. (2007) Newborn Screening Coupled with Comprehensive Follow-Up Reduced Early Mortality of Sickle Cell Disease in Connecticut. Connecticut Medicine, 71, 9-12.

[14] Platt, O.S., Thorington, B.D., Brambilla, D.J., Milner, P.F., Rosse, W.F., Vichinsky, E. and Kinney, T.R. (1991) Pain in Sickle Cell Disease. Rates and Risk Factors. The New England Journal of Medicine, 325, 11-16. https://doi.org/10.1056/NEJM199107043250103

[15] Cataldo, G., Rajput, S., Gupta, K. and Simone, D.A. (2015) Sensitization of Nociceptive Spinal Neurons Contributes to Pain in a Transgenic Model of Sickle Cell Disease. Pain, 156, 722-730. https://doi.org/10.1097/j.pain.0000000000000104

[16] Hillery, C.A., Kerstein, P.C., Vilceanu, D., Barabas, M.E., Retherford, D., Brandow, A.M., Wandersee, N.J. and Stucky, C.L. (2011) Transient Receptor Potential Vanilloid 1 Mediates Pain in Mice with Severe Sickle Cell Disease. Blood, 118, 3376-3383. https://doi.org/10.1182/blood-2010-12-327429

[17] Kohli, D.R., Li, Y., Khasabov, S.G., Gupta, P., Kehl, L.J., Ericson, M.E., Nguyen, J., Gupta, V., Hebbel, R.P., Simone, D.A. and Gupta, K. (2010) Pain-Related Behaviors 
and Neurochemical Alterations in Mice Expressing Sickle Hemoglobin: Modulation by Cannabinoids. Blood, 116, 456-465.

https://doi.org/10.1182/blood-2010-01-260372

[18] Valverde, Y., Benson, B., Gupta, M. and Gupta, K. (2016) Spinal Glial Activation and Oxidative Stress Are Alleviated by Treatment with Curcumin or Coenzyme Q in Sickle Mice. Haematologica, 101, e44-e47. https://doi.org/10.3324/haematol.2015.137489

[19] Vincent, L., Vang, D., Nguyen, J., Benson, B., Lei, J. and Gupta, K. (2015) Cannabinoid Receptor Specific Mechanisms to Ameliorate Pain in Sickle Cell Anemia via Inhibition of Mast Cell Activation and Neurogenic Inflammation. Haematologica, 101, 566-577.

[20] Powars, D.R., Chan, L.S., Hiti, A., Ramicone, E. and Johnson, C. (2005) Outcome of Sickle Cell Anemia: A 4-Decade Observational Study of 1056 Patients. Medicine, 84, 363-376. https://doi.org/10.1097/01.md.0000189089.45003.52

[21] Raphael, J.L., Dietrich, C.L., Whitmire, D., Mahoney, D.H., Mueller, B.U. and Giardino, A.P. (2009) Healthcare Utilization and Expenditures for Low Income Children with Sickle Cell Disease. Pediatric Blood \& Cancer, 52, 263-267. https://doi.org/10.1002/pbc.21781

[22] Embury, S.H. (1987) The Different Types of Alpha Thalassamia Genetic Aspects. Hemoglobin, 11, 592.

\section{Submit or recommend next manuscript to SCIRP and we will provide best} service for you:

Accepting pre-submission inquiries through Email, Facebook, LinkedIn, Twitter, etc. A wide selection of journals (inclusive of 9 subjects, more than 200 journals) Providing 24-hour high-quality service User-friendly online submission system Fair and swift peer-review system Efficient typesetting and proofreading procedure Display of the result of downloads and visits, as well as the number of cited articles Maximum dissemination of your research work

Submit your manuscript at: http://papersubmission.scirp.org/ Or contact ojepi@scirp.org 